\title{
Effect of Dietary Inclusion of Leucaena (Leucaena leucocephala) and Banana Flour (Musa cavendishii) on Performance of Laying Hens
}

\section{mAuthor(s)}

Dumorné K' (iD https://orcid.org/0000-0002-1007-0876 Department of Engineering Chemical of Universidad de la Frontera, Avenida Francisco Salazar 01145, Box 54D. Temuco 4811230, Chile.

\section{nail Address}

Corresponding author e-mail address Kelly Dumorné

Department of Engineering Chemical of Universidad de la Frontera, Avenida

Francisco Salazar 01145, Box 54D.

Temuco 4811230, Chile.

Phone: +56 957552024

Email: k.dumorne01@ufromail.cl

\section{nKeywords}

Animal diet, Banana flour, laying hens, Leucaena.

\section{ABSTRACT}

The aim of the present study was to evaluate the effects of Leucaena (Leucaena leucocephala) and Banana flour (Musa cavendishii) on performance of laying hens. Fifty laying hens (3 months of age) were randomly distributed into five experimental groups, each consisting of 10 laying hens. The groups were control (10 laying hens); $L_{6}$ (Leucaena, $6 \mathrm{~g} /$ day (10 laying hens)); $\mathrm{L}_{8}$ (Leucaena, $8.0 \mathrm{~g} /$ day (10 laying hens)); $\mathrm{L}_{10}$ (Leucaena, $10 \mathrm{~g} /$ day (10 laying hens)); and $\mathrm{L}_{12}$ (Leucaena, $12 \mathrm{~g} /$ day (10 laying hens)), in addition, five levels of Banana flour control (10 laying hens); 25\% (10 laying hens); 50\%, (10 laying hens); 75\% (10 laying hens); and 100\% (10 laying hens), were assessed respectively. The experimental period lasted from 4 to 8 weeks. The results of this study showed that there were no significant differences between of treatments $L_{6}, L_{8} L_{10}$, and $L_{12}$ for body weight during the first 30 days compared with the control, whereas for weight gain, statistically significant differences were observed between the control compared with the treatments $L_{6}, L_{8} L_{10}$ and $L_{12}$ for days 10, 20 and 30 ( $p<0.05$ ).

Additionally, statistically significant differences were found between different levels of Banana flour for weight gain ( $\mathrm{g}$ ) between the control with the levels 25, $5075,100 \%$, respectively for days 20 and 30 . In the case of feed intake (g) statistically significant differences were found during day 30 between the control and $100 \%$, also between the control and levels 25 , and $75 \%$, respectively. From the results, it can be concluded that the inclusion of Leucaena and banana flour have effects on weight gain, body weight and feed intake of laying hens.

\section{INTRODUCTION}

Many of the traditional ingredients used in hen's diets are forecast to be in short supply within ten years. Leucaena (Leucaena leucocephala) is a plant native to Central America, it is grown extensively in many parts of the world (Agbede, 2003). This plant is considered as a protein source for the poultry sector (Alkarkhi et al., 2011). It is a plant rich in nutrients with high digestibility fibers, however, it contains toxic amino acid as the mimosine that are found mainly in the leaves and the dried seeds (Atawodi et al., 2010; Mutayoba et al., 2011). According to Dilger et al. (2004), the use of ingredients with high fiber levels in poultry diets may reduce the digestibility of nutrients and increase nitrogen excretion. Safwat et al. (2014) have reported the importance of Leucaena in the laying hen's diets. Studies on Leucaena showed that the leaves are rich in energy, protein, and vitamins (Nieves et al., 2004; Ayssiwede et al., 2011). Limited research was published about the use of Banana flour in animal feed, in particular laying hens.

Banana, is the fourth plant more produced in the world with over 7 million tons (Ribiero et al., 2012). It contains as high as 74\% starch 
on dry matter basis (Babatunde 1992). Banana is rich in dietary fibre, proteins, essential amino acids, cellulose, hemicelluloses, lignin, starch, resistant starch, polyunsaturated fatty acids and potassium (RodríguezAmbriz et al., 2008; Sarawong et al., 2014). Currently, industrial flour production from green banana is of interest in view of its nutritional value, especially the high quantity of resistant starch between 40.9-58.5 $\%$ and dietary fibre 6.0-15.5 \% (Tribess et al., 2009; Sarawong et al., 2014). It has high starch content and is widely used in animal feed (Martinez et al., 2009). Despite of being a valuable nutritional component, the lack of use in animal diet constitutes a very nutritional due to contains extractable bioactive compounds, which can be used as value-added materials (Safwat et al., 2014). It is projected that the utilization of Leucaena and Banana flour is to be a sustainable resource for laying hens production and diet, as they are easily available and contain a considerable amount of nutrients. The purpose of this study was to assess the effects of Leucaena leucocephala and Banana flour on performance of laying hens.

\section{MATERIALS AND METHODS}

\section{Animals, experimental treatments and diet}

The experiment was performed housing a total of 50 laying hens in a poultry facility at the University of State (Haiti). They were randomly selected from State University farm, and each laying hen was placed in individual cages. The facility was $10 \times 25$ meters with four ventilators and 4 windows, and a total of 15 landpens $(1.6 \times 0.8 \mathrm{~m})$ were used. Ventilation was turned on to optimize the climate $24 \mathrm{~h}$ before the laying hens were brought in.

Air humidity was kept at 60 to $65 \%$ in the early growing period by spraying water on the floor. Lamps were installed at a height of 2.2 meters above the floor. The water supply was through drinkers, one for each hen and the food supply was a feeder per hen. The experimental design included five experimental groups of 10 laying hens each. The dietary treatments were as follows: Control (10 laying hens); $\mathrm{L}_{6}$ (Leucaena, $6 \mathrm{~g} /$ day (10 laying hens)); $L_{8}$ (Leucaena, $8.0 \mathrm{~g} /$ day (10 laying hens)); 3) $L_{10}$ (Leucaena, $10 \mathrm{~g} /$ day (10 laying hens)); and 4) $L_{12}$ (Leucaena, 12 g/day (10 laying hens)), in addition, five levels of Banana flour: Control (10 laying hens); 25\% (10 laying hens); 50\%, (10 laying hens); $75 \%$ (10 laying hens) and 100\% (10 laying hens) were assessed.

\section{Chemical composition and chemical analyses of experimental diets}

Chemical composition and chemical analyses of experimental diets of Leucaena and banana flour were determined using the standard AOAC (2000) procedures to determine dry matter $(D M)$, organic matter (OM), ether extract (EE), crude fiber (CF), and crude protein $(C P)$ content. Neutral detergent fiber (NDF) and acid detergent fiber (ADF) as sequential method were performed according to Van Soest et al. (1991). Tables 1, 2 and 3 show the composition and chemical analyses of experimental diets containing different levels of Leucaena leucocephala and Banana flour.

Table 1 - Composition and chemical analyses of experimental diets containing different levels of Leucaena leucocephala.

\begin{tabular}{|c|c|c|c|c|}
\hline \multirow{2}{*}{$\frac{\text { Treatments }}{\text { Leaf meal }}$} & \multicolumn{4}{|c|}{ Ingredients (\%) } \\
\hline & 6 & 8 & 10 & 12 \\
\hline Sorghum & 57.34 & 56.00 & 54.46 & 52.22 \\
\hline Soya bean meal & 15.45 & 15.12 & 14.56 & 12.69 \\
\hline $\mathrm{CaCO}_{3}$ & 8.75 & 8.10 & 7.8 & 7.46 \\
\hline Canola meal & 5.00 & 5.00 & 5.00 & 5.00 \\
\hline Corn stover & 3.00 & 3.00 & 3.00 & 3.00 \\
\hline Soya oil & 1.92 & 2.29 & 2.5 & 3.48 \\
\hline Di-Cal-phosphate & 1.56 & 1.46 & 1.38 & 2.3 \\
\hline Lysine & 0.18 & 0.27 & 0.38 & 0.80 \\
\hline Methionine & 0.21 & 0.17 & 0.33 & 0.46 \\
\hline $\mathrm{NaCl}$ & 0.30 & 0.30 & 0.30 & 0.30 \\
\hline Mycosorb & 0.10 & 0.10 & 0.10 & 0.10 \\
\hline Funginat & 0.05 & 0.05 & 0.05 & 0.05 \\
\hline Choline chloride & 0.05 & 0.05 & 0.05 & 0.05 \\
\hline Vita. and Min. premix & 0.08 & 0.08 & 0.08 & 0.08 \\
\hline Anti-oxidant & 0.01 & 0.01 & 0.01 & 0.01 \\
\hline Total & 100.00 & 100.00 & 100.00 & 100.00 \\
\hline \multicolumn{5}{|c|}{ Chemical analysis (calculated as \% on DM basis) } \\
\hline Dry matter (\%) & 87.25 & 89.56 & 90.34 & 90.44 \\
\hline Gross energy (kcal/kg) & 15.68 & 16.24 & 15.46 & 17.15 \\
\hline Crude protein (\%) & 19.60 & 19.76 & 20.10 & 20.46 \\
\hline $\operatorname{ADF}(\%)$ & 8.4 & 9.10 & 9.34 & 9.88 \\
\hline $\operatorname{NDF}(\%)$ & 54.45 & 58.20 & 59.38 & 61.22 \\
\hline Calcium (\%) & 3.12 & 3.44 & 4.22 & 4.66 \\
\hline Phosphorus (\%) & 0.56 & 0.52 & 0.45 & 0.36 \\
\hline Ash (\%) & 12.80 & 12.42 & 11.78 & 11.33 \\
\hline
\end{tabular}

aContent kg-1 of diet: Manganese, $62 \mathrm{mg}$; iodine, $1 \mathrm{mg}$; iron, $53 \mathrm{mg}$, copper, $5 \mathrm{mg}$; zinc, $54 \mathrm{mg}$; selenium, $0.2 \mathrm{mg}$; vitamin A, $8000 \mathrm{Ul}$; vitamin D, $2500 \mathrm{UI}$; vitamin E, $8 \mathrm{Ul}$; vitamin $\mathrm{K}, 2 \mathrm{mg}$; vitamin B12, $0.001 \mathrm{mg}$; riboflavin, $5.3 \mathrm{mg}$; pantothenate of calcium, $12 \mathrm{mg}$; niacin, $33 \mathrm{mg}$; choline, $500 \mathrm{mg}$; folic acid, $0.5 \mathrm{mg}$; thiamine, $1 \mathrm{mg}$; pyridoxine, $2.1 \mathrm{mg}$; biotin, $0.04 \mathrm{mg}$.

\section{Performance parameters}

Feed intake (g/day), Body weight (g/day) and Weight gain (Final weight - Initial weight) were determined weekly. 


\section{Leucaena preparation}

Leucaena was prepared according to protocol described by Abou-Elezz et al. (2011). Leucaena fresh leaves were collected from trees growing at Port-auPrince, under the tropical conditions of Haiti. The branches were cut from trees; leaves were separated from branches, spread out, and dried under shade for a period of 2 days. Afterwards, they were dried in ovens $\left(70^{\circ} \mathrm{C}\right)$ for 2 days. The dried leaves were crushed with a hammer mill to make the Leucaena, which were incorporated to the experimental diets.

\section{Banana flour preparation}

The bananas were produced and collected by the State University farm, they were chopped into pieces to facilitate drying. The fragments of the bananas were dried in an oven at a temperature of $60^{\circ} \mathrm{C}$ for 2 days. Additionally, they were ground and transformed into flour. Table 2 shows the composition of Banana flour of diets for laying hens.

Table 2 - Composition and chemical analyses of the experimental of diets for laying hens.

\begin{tabular}{lccccc}
\hline Ingredients & $0 \%$ & $25 \%$ & $50 \%$ & $75 \%$ & $100 \%$ \\
\hline Banana flour & 0 & 26.5 & 35.05 & 40.56 & 54.08 \\
Hominy & 54.08 & 27.58 & 19.03 & 13.52 & 0 \\
Soy & 40.45 & 40.45 & 40.45 & 40.55 & 40.45 \\
Methionine & 0.08 & 0.08 & 0.08 & 0.08 & 0.08 \\
Zinc-bacitracin & 0.05 & 0.05 & 0.05 & 0.05 & 0.05 \\
Fat & 1 & 1 & 1 & 1 & 1 \\
Limestone & 3.34 & 3.34 & 3.34 & 3.34 & 3.34 \\
NaCl & 0.25 & 0.25 & 0.25 & 0.25 & 0.25 \\
Vitamin-mineral & 0.25 & 0.25 & 0.25 & 0.25 & 0.25 \\
Mycotoxin & 0.5 & 0.5 & 0.5 & 0.5 & 0.5 \\
Total & 100 & 100 & 100 & 100 & 100 \\
\hline
\end{tabular}

Table 3 - Composition and chemical analyses of Banana flour.

\begin{tabular}{lcccccc}
\hline Banana flour & \multicolumn{6}{c}{ Nutrients content (dry matter) } \\
\hline & DM & CP & EE & CF & ADF & NDF \\
\hline $0 \%$ & 94.98 & 24.37 & 2.80 & 15.60 & 22.00 & 60.00 \\
$25 \%$ & 97.99 & 27.47 & 3.00 & 14.40 & 47.00 & 64.00 \\
$50 \%$ & 96.74 & 26.11 & 3.60 & 12.80 & 46.00 & 63.00 \\
$75 \%$ & 95.78 & 22.57 & 2.00 & 11.80 & 43.00 & 86.00 \\
$100 \%$ & 96.64 & 23.31 & 1.40 & 10.40 & 49.00 & 87.00 \\
\hline
\end{tabular}

DM dry matter, CP crude protein, EE ether extract, CF crude fiber, ADF acid detergent fiber, NDF neutral detergent fiber.

\section{Statistical analysis}

The data were expressed as mean values \pm standard deviation (SD) and were analyzed by analysis of variance using a one-way ANOVA procedure based on a completely randomized design. The GraphPad Prisma ${ }^{\circledR}$ version 6.0 statistical software (GraphPad Software, San Diego (A) was also used to analyze the data. The analysis of differences between the average values of the treatment groups were compared by application of Tukey's tests. The level of significance was set at $p<0.05$.

\section{RESULTS}

\section{Chemical composition}

Data for chemical analysis of Leucaena leucocephala and Musa cavendishii are illustrated in Tables 1 and 3.

\section{Growth Performances}

No differences $(p<0.05)$ between the Control and the groups of treatments on Body weight were observed during the first 30 days. Regarding, weight gain, statistically significant differences $(p<0.05)$ were observed between the Control $(3.01 \pm 0.75)$ and of the treatments $L_{8}(0.45 \pm 0.15 \mathrm{~g}), L_{10}(0.34 \pm 0.17 \mathrm{~g})$, and $L_{12}(0.60 \pm 0.07 \mathrm{~g})$ on the $10^{\text {th }}$ day. In addition, on day 20 , statistically significant differences $(p<0.05)$ were observed between the Control $(4.23 \pm 2.08 \mathrm{~g})$ and the $\mathrm{L}_{10}(0.25 \pm 1.13 \mathrm{~g})$. On the $30^{\text {th }}$ day, statistically significant differences $(p<0.05)$ were observed between the Control $(2.23 \pm 1.65 \mathrm{~g})$ and the treatments $\mathrm{L}_{6}(0.20$ $\pm 0.07 \mathrm{~g}), \mathrm{L}_{8}(0.05 \pm 0.03 \mathrm{~g}) \mathrm{L}_{10}(0.08 \pm 0.03 \mathrm{~g})$ and $\mathrm{L}_{12}$ $(0.05 \pm 0.03 \mathrm{~g})$, respectively' (Table 4$)$.

There was no significant difference in Weight gain during the days 15, 20 and 25 between the Control and the levels 25, 5075 and $100 \%$ respectively, while on the $30^{\text {th }}$ day statistically significant differences $(p<0.05)$ were observed between the Control $(21.67 \pm 0.6 \mathrm{~g})$ and the $25 \%(4.87 \pm 0.02 \mathrm{~g})$ and $75 \%(9.67 \pm 0.2$ g). For feed intake, statistically significant differences were observed on the $15^{\text {th }}$ day at level $100 \%$ (17.92 $\pm 1.47 \mathrm{~g})$ comparing with the Control $(25.40 \pm 2.01$ g). However, on day 20, the feed intake was increased significantly between the Control $(11.34 \pm 0.9 \mathrm{~g})$ and the level $100 \%(2.45 \pm 0.90 \mathrm{~g})$.

There was no significant difference during day 25 , whereas for day 30 statistically significant differences were observed between the Control $(9.81 \pm 1.02 \mathrm{~g})$ and the levels $25 \%(1.72 \pm 1.78 \mathrm{~g})$ and $75 \%(4.16$ $\pm 2.2 \mathrm{~g}$ ), respectively). The results revealed that the highest feed intake values were observed for the level $25 \%(30.84 \pm 2.01 \mathrm{~g})$ on day $15,50 \%(16.30 \pm 2.9 \mathrm{~g})$ on day $20,100 \%(11.81 \pm 2.8 \mathrm{~g})$ on day 25 , and the Control $(9.81 \pm 1.02 \mathrm{~g})$ on day 30 (Table 5 ). 
Table 4 - Effect of dietary treatments on body weight and weight gain of laying hens*.

\begin{tabular}{|c|c|c|c|c|c|}
\hline \multirow[b]{2}{*}{ Variable } & \multicolumn{5}{|c|}{ Dietary treatments of Leucaena leucocephala } \\
\hline & Control & $\mathrm{L}_{6}$ & $\mathrm{~L}_{8}$ & $\mathrm{~L}_{10}$ & $L_{12}$ \\
\hline \multicolumn{6}{|l|}{ Body weight (g) } \\
\hline Day 0 to 1 & $1598.34 \pm 34.76^{a}$ & $1410.60 \pm 86.86^{a}$ & $1413.20 \pm 86.44^{\mathrm{a}}$ & $1494.80 \pm 211.44^{\mathrm{a}}$ & $1592.00 \pm 2.00^{\mathrm{a}}$ \\
\hline Days 10 to 20 & $1609.07 \pm 25.33^{a}$ & $1425.40 \pm 87.06^{a}$ & $1416.40 \pm 86.82^{\mathrm{a}}$ & $1497.20 \pm 210.66^{a}$ & $1596.20 \pm 2.01^{\mathrm{a}}$ \\
\hline Days 20 to 30 & $1617.67 \pm 46.78^{a}$ & $1443.00 \pm 89.90^{\mathrm{a}}$ & $1425.20 \pm 87.54^{a}$ & $1499.00 \pm 210.28^{a}$ & $1607.40 \pm 1.77^{a}$ \\
\hline Days 0 to 30 & $1611.09 \pm 28.33^{a}$ & $1444.40 \pm 90.16^{a}$ & $1425.60 \pm 87.35^{\mathrm{a}}$ & $1499.60 \pm 210.30^{a}$ & $1607.80 \pm 1.77^{a}$ \\
\hline \multicolumn{6}{|l|}{ Weight gain $(\mathrm{g})$} \\
\hline Day 10 & $3.01 \pm 0.75^{\mathrm{ab}}$ & $2.11 \pm 1.15^{\mathrm{a}}$ & $0.45 \pm 0.15^{\mathrm{a}}$ & $0.34 \pm 0.17^{\mathrm{a}}$ & $0.60 \pm 0.07^{a}$ \\
\hline Day 20 & $4.23 \pm 2.08^{\mathrm{ab}}$ & $2.51 \pm 0.53^{\mathrm{a}}$ & $1.25 \pm 0.18^{\mathrm{ab}}$ & $0.25 \pm 1.13^{b}$ & $1.59 \pm 0.19^{\mathrm{ab}}$ \\
\hline Day 30 & $2.23 \pm 1.65^{\mathrm{ab}}$ & $0.20 \pm 0.07^{a}$ & $0.05 \pm 0.03^{a}$ & $0.08 \pm 0.03^{a}$ & $0.05 \pm 0.03^{a}$ \\
\hline
\end{tabular}

Control; $\mathrm{L}_{6}$ (Leucaena, $6 \mathrm{~g} /$ day); $\mathrm{L}_{8}$ (Leucaena, $8 \mathrm{~g} /$ day); $\mathrm{L}_{10}$ (Leucaena, $10 \mathrm{~g} /$ day) and $\mathrm{L}_{12}$ (Leucaena, $12 \mathrm{~g} /$ day).

a,bDifferent letters in the same row and column indicate significant difference in the Tukey's test. $(p<0.05)$.

"Each group consisted of 10 Laying hens.

Table 5 - Effect of dietary treatments on weight gain and effectiveness of laying hens ${ }^{*}$

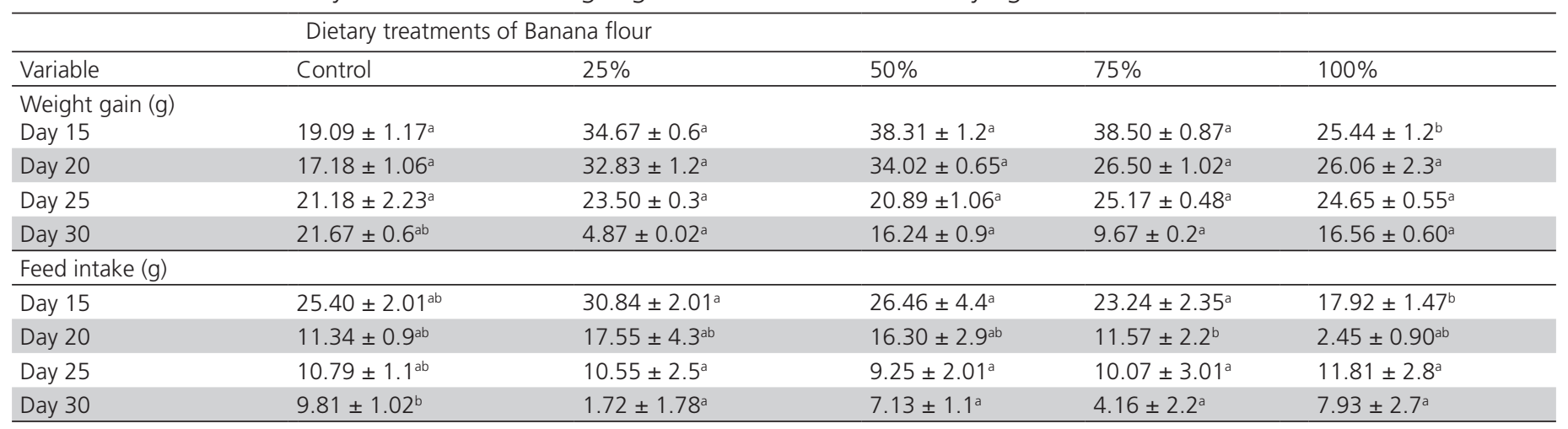

a,bDifferent letters in the same row and column indicate significant difference in the Tukey's test. $(p<0.05)$.

*Each group consisted of 10 Laying hens.

\section{DISCUSSION}

In the present study, at the end of the production cycle, body weight, Weight gain and Feed intake were similar between the treatments and levels compared with the Control. These results are in agreement with similar total feed intake, final body weight observed by Atawodi et al. (2008) in laying hens. Numerous investigations have been reported that the inclusion of L. leucocephala has effects in the diets regarding the performance of laying hens (Nunes de Oliveira et al., 2014). Nuhu (2010) and Abou-Elezz et al. (2011) have reported that the variations in the nutrients composition of Leucaena could be attributed to various factors such as plants age, climatic conditions, agronomic practices as well as methods of processing and analysis. The results of this research showed that the Leucaena plays an important role in the diet of laying hens. A study realized by Lu et al. (2016) has shown that leucaena could improve dietary of the animals. Although in our study, the feed intake at day 30 for the level of $25 \%$ $(1.72 \mathrm{~g})$ was lower compared with the Control $(9.81 \mathrm{~g})$.
The nutrition of the animals is very important, it directly influences egg quality and the economic income in the poultry industry. Few researchers have used Banana flour in laying hen diets.

As shown in Table 4, the weight of laying hens increased after days 15 and 25 (38.50 and $25.17 \mathrm{~g}$ ) in response to $75 \%$ of Banana flour, whereas, for day 30 , the weight increased to $100 \%$ (16.56 g). The increased feed intake of banana flour suggested that it does not contain anti-nutrients that reduce the feed intake of laying hens. Another study realized by Adeniji et al. (2007) found that banana contained low levels of anti-nutrients such as tannins, phytates and oxalates. The results of this experiment clearly showed that Banana flour can be used up to $100 \%$ in the diet of laying hens. Currently, there are few studies on the use of Banana flour in the diet of laying hens. The present study suggested that the Leucaena and Banana flour could be used to improve the performance of laying hens. Utilization of Leucaena and Banana flour can reduce the budget for feed in poultry sector. Future researches need to try 
the use of Leucaena and Banana flour in other animals of poultry sector. Finally, the use of these flours can be used as a partial substitute for the protein specially in laying hens

\section{CONCLUSIONS}

This study has demonstrated that the feed intake of laying hens varies between the different levels. Due to the high price of protein ingredient, Leucaena and Banana flour can be useful as a good alternative of animal feed, as they are low cost production. Therefore, Leucaena and Banana flour may be an alternative food resource to implement sustainable laying hen's production in tropical countries as Haiti, it can be included to growing laying hen' s diets. In addition, Leucaena and Banana flour are an effective way to enhance nutrition for the laying hens. Based on the results, it can be concluded that Leucaena leucocephala and Banana flour can be used as protein in the diets of laying hens. Therefore, the data in our study may provide the basis for future research.

\section{ACKNOWLEDGEMENTS}

The authors would like to thank FONDECYT $N^{\circ}$ 1151315 (Dr. Jorge Farías), Universidad de la Frontera, Temuco, Chile for the Scholarships for PhD in Chile $(K D)$.

\section{REFERENCES}

Abou-Elezz FMK, Sarmiento-Franco L, Santos-Ricalde R, Solorio-Sánchez F. Nutritional effects of dietary inclusion of Leucaena leucocephala and Moringa oleifera leaf meal on Rhode Island Red hens' performance. Cuban Journal of Agricultural Science 2011;45:163-169.

Adeniji TA, Sanni LO, Barimalaa IS, Hart AD. Nutritional and anti-nutritional composition of flour made from plantain and banana hybrid pulp and peel mixture. Nigerian Food Journal 2007;25:68-76

Agbede JO. Equi-protein replacement of fishmeal with leucaena leaf protein concentrate:An assessment of performance characteristics and muscle development in the chicken. International Journal Poultry Science 2003;6:421-429

Alkarkhi AF, Ramli SB, Yong YS, Easa AM. Comparing physicochemical properties of banana pulp and peel flours prepared from green and ripe fruits. Food Chemistry 2011;129:312-318.

AOAC - Association of Official Analytical Chemists. Official methods of analysis. $17^{\text {th }}$ ed. Washington; 2000.
Atawodi SE, Mari D, Atawodi JC, Yahaya Y. Assessment of Leucaena leucocephala leaves as feed supplement in laying hens. African Journal of Biotechnology 2008;7:317-321.

Ayssiwede SB, Dieng A, Chrysostome C, Ossebi W, Hornick JL, Missohou A. Digestibility and metabolic utilization and nutritional value of Leucaena leucocephala (Lam.) leaves meal incorporated in the diets of indigenous seneghal chickens. International Journal Poultry Science 2010;9:767-776.

Babatunde GM. Availability of banana and plantain products for animal feeding. Proceedings of the FAO Expert Consultation Held in CIA, 1991; Cali. Colombia: CIAT; 1991. p.251-276.

Dilger RN, Sands JS, Ragland D, Adeola O. Digestibility of nitrogen and amino acids in soybean meal with added soyhulls. Journal of Animal Science 2004;82:715-724.

Lu W, Wang J, Zhang HJ, Wu SG, Qi GH. Evaluation of Moringa oleifera leaf in laying hens:effects on laying performance, egg quality, plasma biochemistry and organ histopathological indices. Italian Journal of Animal Science 2016;15:658-665.

Martínez MO, Ayerdi S, Gama EC, Goni I, Bello PLA. Unripe banana flour in the ingredient to the increase of carbohydrate indigestible paste. Food Chemistry 2009;113:121-126.

Mutayoba SK, Dierenfeld E, Mercedes VA, Frances $Y$, Knight CD. Determination of chemical composition and antnutritive components for Tanzanian locally available poultry feed ingredients. International Journal of Poultry Science 2011;10:350-357.

Nieves D, Basilia S, Teran O, González C, Ly J. Anote on the chemical composition and feeding characteristics of diets containing Leucaena leucocephala and Arachis pintoi for growing rabbits. Livestock Research for Rural Development 2004;16:99.

Nunes de Oliveira L, Freitas Braga ER, Thales CE, Filgueira MB, Jerônimo do Nascimento GA, Lima RC. Inclusion of leucaena leaf hay in the diet of laying hens during the growing phase. Acta Scientiarum. Animal Sciences 2014;36:297-301.

Rodríguez-Ambriz SL, Islas-Hernández JJ, Agama-Acevedo E, Tovar J, Bello-Pérez LA. Characterization of a fibre rich powder prepared by liquefaction of unripe banana flour. Food Chemistry 2008;107:15151521.

Sarawong C, Schoenlechner R, Sekiguchi K, Berghofer E, Ng PKW. Effect of extrusion cooking on the physicochemical properties, resistant starch phenolic content and antioxidant capacities of green banana flour. Food Chemistry 2014;14:33-39.

Safwat AM, Sarmiento-Franco L, Santos-Ricalde RH, Nieves D. Determination of tropical forage preferences using two offering methods in rabbits. Asian Australasian Journal of Animal Science 2014;27:524-529.

Tribess TB, Hernández JP, Montealvo MGC, Menezes EW, Bello-Perez LA, Tadini CC. Thermal properties and resistance starch content of green banana flour (Musa cavendishii) produced at different drying conditions. Food Science and Technology 2009;42:1022-1025.

Van Soest PJ, Robertson JB, Lewis BA. Methods for dietary fiber, neutral detergent fiber and nonstartch polysaccharides in relation to animal nutrition. Journal of Dairy Science 1991;74:3583-3597. 
